\title{
Asian Clam (Corbicula fluminea) Larvae Production in Broodstock Conditioning
}

\author{
Hadiana $^{1 *}$, Aweng Eh Rak ${ }^{2}$, Lee Seong Wei ${ }^{1}$ and M. Zharif ${ }^{1}$ \\ ${ }^{1}$ Faculty of Agro-based Industry. University of Malaysia, Jeli Campus, Kelantan, Kota Bharu, \\ Malaysia \\ ${ }^{2}$ Faculty of Earth Science, University of Malaysia, Jeli Campus, Kelantan, Kota Bharu, Malaysia
}

*Correspondence :

hadiana99@gmail.com

Received : 2019-12-05

Accepted : 2020-06-05

Keywords :

Asian clam, Fine sand, Sediment, Juvenile

\begin{abstract}
Nowadays, the inclining of Asian clam market demand for supplying the seller Etak in some areas in Malaysia particularly Kelantan where etak had become the main concern due to the stock availability in the natural population was over-exploited. Thus, an effort to expedite the availability seed of Etak must be initiated to conserve the Asian clam population in their habitat. Until now, the information about production larvae is needed to begin the domestication process. The scientific goal aims to evaluate the best time to produce Asian clam larvae to supply the hatchery production process. To answer this question, the evaluation of broodstock conditioning adult Corbicula fluminea monthly during a year and this condition was compared into the fine sand sediment as well as no sediment. The results showed that the Asian clam adult pattern released larvae monthly during a year wherein the great number larvae were produced 22464 Ind/L totally in December and the produced larvae in Oct and Nov was almost similar with range $22350-22500$ Ind/L. The condition index with fine sand sediment was $3.8419 \%$ higher than the control treatment $3.5750 \%$. And last, the ingestion rate both treatment was $1.126 \pm 0.534 \mu \mathrm{g} / \mathrm{h}$ and control treatment $1.609 \pm 0.434 \mu \mathrm{g} / \mathrm{h}$.
\end{abstract}

\section{INTRODUCTION}

In recent years, the state of Kelantan area has seen significant advances in Asian clam, Etak becomes the commodity species in Malaysia, especially in Kelantan state. This species revealed the great potential to domestication process (Aquaculture) where the information of all life cycles is needed such pattern of production larvae (Rak, 2006). However, until now the insufficient information for this stage becomes the main problem to the aquaculture process (Cheng, 2015). Therefore, the information is needed to monitor the Asian clam reproduction activity to gain valued insight for harvester where the great number of larvae would be released monthly during a year to comply with the rearing process.

The stock availability in nature occurred over-exploitation where this condition causes negative repercussions, such as ecological instability (Lee et al., 2013). Corbicula fluminea is also one of the indigenous fauna filters and pedal feeders, which found in sandy bottoms of rivers in Kelantan (Rak, 2006). The report from Patrick et al. (2017) mentioned that Asian clam preferred habitat with fine or 
coarse sand substrates compared to mud or bare concrete. The support research found as well that substrates influence the distribution of this clam (Colwell et al., 2017). The scientific goal aims to monitor the pattern of Asian clam larvae production to supply the hatchery production process.

\section{METHODOLOGY}

\section{Place and Time}

The experiment was conducted during October 2018-September 2019, and then the hatchery Asian clam larvae production in this study was addressed at the Aquaculture Laboratory, Faculty of Agro-based Industry at UMK Campus Jeli, and the sampling location at around Kampung Kubang Batang, Tumpat (6 $\left.1332.8 \mathrm{~N} 102^{\circ} 1521.7 \mathrm{~S}\right)$.

\section{Research Material}

The tools used include aquariums, aerators, autoclaves, analytical balances, laminar flow, test tubes, petri dishes, glass microfiber filter (GFC, Whatman, pore size 60 and $150 \mu \mathrm{m}$ ) calipers, microalgae, and microscope. Adult Samples are taken from the catch at $\mathrm{Kg}$ Kubang Batang River.

The water parameter was evaluated by using DR-2800 spectrophotometer (Hach, Germany) referring to the company manual in the laboratory setting (Filgueira et al., 2013).

\section{Research Design}

The experiment design in this research was explained in Figure 1.

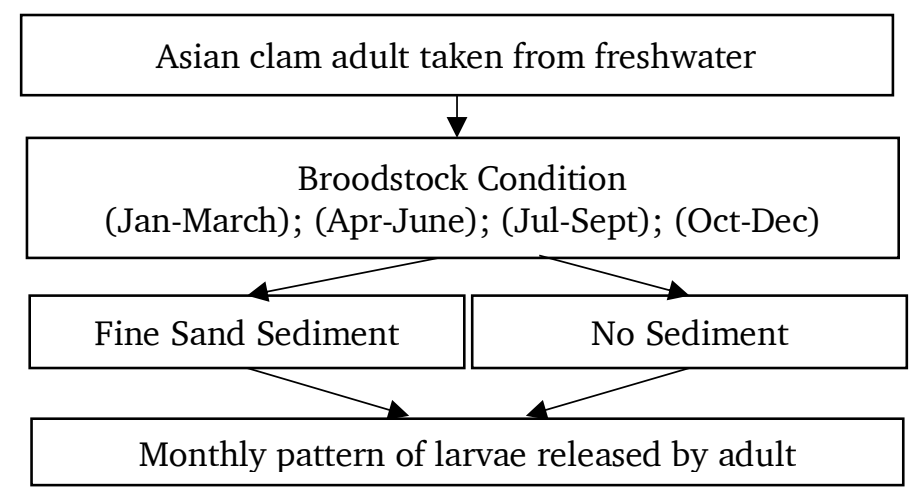

Figure 1. Experiment design of Asian clam production.

\section{Work Procedures}

\section{Sampling and Handling the Sample}

In the present research, the adult Asian clams were taken from Kg Kubang Batang River by a random sampling method with shell length standard size $>10 \mathrm{~mm}$, which is indicated ready for the spawning process. The taking sample process has utilized the grab for taking benthos (Filgueira et al., 2013) then after that, the samples were cleaned, next to measuring the clam using the ruler, and last the sample should be selected with the needed standard size.

\section{Broodstock Conditioning}

Conditioning is the process of inducing gametogenesis, or the ripening of gonads, to make clams ready for spawning. This process was crucial due to if the conditioning unsuccessful, the larvae could not be released with a great number (Rajagopal et al., 2000). In the present research, 90 adult Corbicula fluminea taken from the freshwater was brought into three tanks for broodstock condition (30 clams for each treatment). This condition was divided into 2 treatments such as control (no sediment) and fine sand sediment with sediment standard size $0.25-0.125 \mathrm{~mm}$. Afterward, make sure the water quality conditions (temperature and dissolved oxygen (DO) levels) were in 
good condition by $\mathrm{DO}$ meter, $\mathrm{pH}$ and salinity used $\mathrm{pH}$ meter, and for ammonia using a spectrophotometer at $650 \mathrm{~nm}$ (Filgueira et al., 2013). Before the clam was entered into the tank, it was estimated shell length, shell height, and shell width. The last, the broodstock conditioning was given feed 100 micros let freshwater microalgae two times a week. Afterward, the Asian clam was settled 24-36 h to release larvae. This process was monthly replication during a year could be seen as an example in Figure 2 Dec-time.

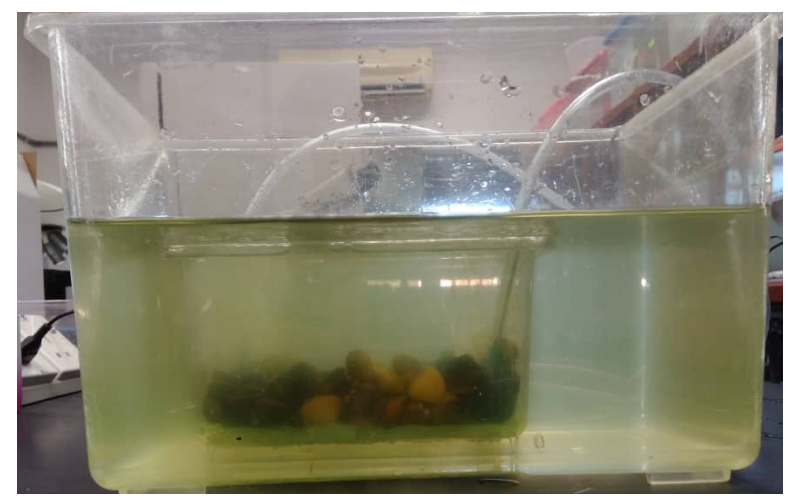

Figure 2. Broodstock conditioning system of Asian clam with no sediment (Dec-time).

Condition index (CI) was determined according to formula given in Scarlet et al. (2015) as:

$\mathrm{CI}=\frac{\mathrm{DmW}}{\mathrm{DsW}} \mathrm{x} 100 \%$

Note:

DmW = dry meat weight $(\mathrm{g})$

DsW = dry shell weight $(\mathrm{g})$

The measuring process for condition index, the all adult from tank broodstock conditioning was taken then it measured the dry meat weight the clam and dry shell weight using a digital scale. This process was replicated monthly for a year. The dry meat process was conducted by a drying oven with a temperature of around 60-70 ${ }^{\circ} \mathrm{C}$.

The clearance rate is that the volume of water is completely cleared of particles per unit of time. When all particles presented to the gill are cleared from suspension, then the clearance rate is the same as the filtration rate. For the Asian clam larvae according to Willadino et al. (2012), the measurement could be using a $10 \%$ number of feeding on an adult. To measure microalgae density the following formula could be used:

$\mathrm{MD}=\frac{\overline{\mathrm{x}} \text { cells }}{\text { square }} \times$ dilution factor $\times 10^{4}$

Note:

$\mathrm{MD}=$ microalgae density

$\bar{x}$ cells $=$ the average number of cells

The measuring process of larvae number was done by taking $1 \mathrm{~L}$ water from larvae tank, then put on the hemocytometer using an automatic pipette (Utting and Spencer, 1991) (Figure 3).

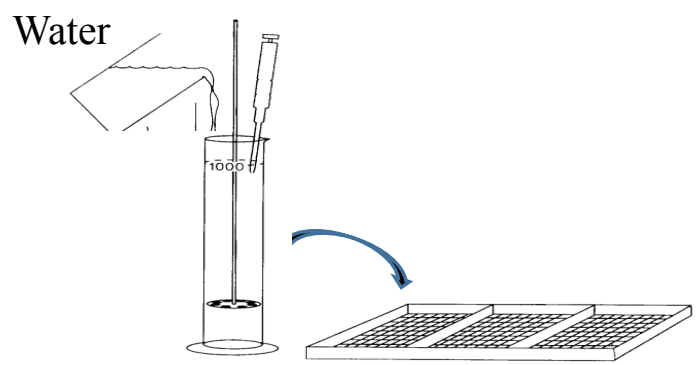

Figure 3. Method for estimating numbers of larvae. 
The ingestion growth rate (IGR) was estimated according to Willadino et al. (2012):

IGR $=(\mathrm{C} 0-\mathrm{C} 1) \times$ water volume $\times \mathrm{h}$

Note:

$\mathrm{C} 0$ = initial food concentration

$\mathrm{C} 1$ = final food concentration

$\mathrm{h}=$ exposure time

\section{Data Analysis}

Data analysis was performed by analysis of variance (ANOVA) by using
Turkey's Honestly Significant Difference post hoc test.

\section{RESULTS AND DISCUSSION}

Broodstock Condition System of Asian Clam (Corbicula fluminea) Condition Index (CI)

The condition index of Asian clam in two treatments (with fine sand sediment and no sediment) could be seen as following (Table 1).

Table 1. The condition index of Asian clam with two treatments during a year.

\begin{tabular}{cccc}
\hline \multirow{2}{*}{ Time } & \multicolumn{2}{c}{ Condition Index (\%) } & \multirow{2}{*}{ CI (\%) } \\
\cline { 2 - 3 } & Fine Sand Sediment & Without Sediment & \\
Jan & 3.7098 & 3.4056 & \multirow{2}{*}{3.7171} \\
Feb & 3.7397 & 3.3265 & \\
Mar & 3.7019 & 3.3968 & \multirow{2}{*}{3.7559} \\
Apr & 3.7254 & 3.4331 & \\
May & 3.8353 & 3.5508 & \multirow{2}{*}{3.8227} \\
Jun & 3.7069 & 3.5194 & \\
Jul & 3.8298 & 3.4732 & \multirow{2}{*}{4.0720} \\
Aug & 3.8218 & 3.6072 & \\
Sep & 3.8165 & 3.6235 & \\
Oct & 3.9366 & 3.8389 & \\
Nov & 4.0308 & 3.8186 & \\
Dec & 4.2485 & 3.7108 & \\
Average & $3.8419 \pm 0.1625$ & $3.5587 \pm 0.1662$ & \\
\hline
\end{tabular}

Table 1 depicts that the condition index of Corbicula fluminea with fine sand sediment was $3.8419 \%$ higher, while control treatment $3.5750 \%$. It means the Asian clam on the sediment treatment readier for the spawning stage. However, as general, both condition indexes indicated available to spawning. If we compare to the previous study by Cataldo et al. (2001), the CI was 2.839-6.854\%. We could see as well that the CI based on three months classified, in Oct-Dec was the highest with $4.0720 \%$ compared to other months. According to the present research, we could conclude that in this range month the $C$. fluminea would release the juvenile with a great number.

At this stage, adult clams are prepared for spawning by maintaining the tank's condition index, water parameter, and clearance rate. According to the present results, the condition index (CI) of C. fluminea in the experiment was in the range of $3.5750-3.8419 \%$. These data indicated that $C$. fluminea were ready to reproduce when compared with previous studies. The CI for Corbicula fluminea reported by Cataldo et al. (2001) ranged between $2.839-6.854 \%$. This experiment reveals that the value of $\mathrm{CI}$ analysis was carried out to estimate the reproductive activity of a particular species indirectly or to evaluate the readiness of $C$. fluminea adult for the spawning process. In this present study could indicate the readiness of the $C$. fluminea for realizing the larvae.

According to Rajagopal et al. (2000), the reproductive intensity of bivalves varies with age and size since younger individuals experience rapid growth and invest little to no energy on reproduction. On the other hand, energy allocation transitions gradually from somatic growth and maintenance to reproduction when size increases. Furthermore, poor or stressful 
environmental conditions may lead to a low CI for the clam (McMahon, 2002). CI has also been linked to several factors such as food availability, temperature, salinity, and chemical contaminants (Filgueira et al., 2013).

These water parameters may be significant at local spatial scales, resulting in population diversity in nearby localities (Filgueira et al., 2013). However, the more considerable $\mathrm{CI}$ variability between populations may be better explained by significant spatial scale impacts such as primary productivity than local effects (Costil et al., 2005; Filgueira et al., 2013).

Besides, limited food sources might be the biological explanation of this adverse effect of stocking density on CI given that there is a direct relationship between food availability and bivalve CI (Filgueira et al., 2013). The grazing activity of bivalves, which may exert topdown control on the population of phytoplankton in their habitat, maybe the reason for this observation.

\section{Water Parameters}

In this following Table 2 could be seen the water quality parameters condition in the broodstock system. The given Table 2 reveals about the value water quality parameters on Corbicula fluminea broodstock condition, the first parameters were temperature on range 25- $26^{\circ} \mathrm{C}$ when $\mathrm{pH}$ was 6.9 , DO was $5.9-$ $6.2 \mathrm{mg} / \mathrm{L}$, salinity was $0.02 \pm 0.0022 \mathrm{ppt}$ as well as Ammonia was 0.0858-0.1009 $\mathrm{mg} / \mathrm{L}$. Temperature becomes the most critical parameter for this condition, according to the previous study where the optimum temperature was $26-27^{\circ} \mathrm{C}$.

Table 2. Water quality parameters on the Asian clam broodstock condition system.

\begin{tabular}{ccccc}
\hline Parameters & Control & Fine sand & Optimum & Reference \\
\hline Temperature $\left({ }^{\circ} \mathrm{C}\right)$ & $25.75 \pm 0.650$ & $25.97 \pm 5$ & $26-27$ & McMahon 2002; Rajagopal et al. \\
$\mathrm{pH}$ & $6.95 \pm 0.088$ & $6.98 \pm 0.030$ & $6-7$ & 2000 \\
DO (mg/L) & $5.90 \pm 0.460$ & $6.27 \pm 0.327$ & $>3$ & McMahon 2002 \\
Salinity (ppt) & $0.02 \pm 0.002$ & $0.02 \pm 0.003$ & $14-17$ & McMahon 2002 2002 \\
Ammonia (mg/L) & $0.10 \pm 0.014$ & $0.08 \pm 0.012$ & $<0.2$ & McMahon 2002 \\
\hline
\end{tabular}

The water quality parameters impact broodstock conditioning because this experiment was conducted in a closed water system. The water parameters in the broodstock conditioning system are detailed in Table 2 where all parameter was categorized and support to broodstock condition. McMahon (2002) stated that the most important environmental factor in bivalve reproduction is temperature, which also determines the success of broodstock conditioning. To the gametogenic activity of bivalves to occur, they require water temperatures of at least $15^{\circ} \mathrm{C}$. The right temperature is vital to kickstart multiple stages of reproduction and this is important for $C$. fluminea since it has a bivoltine reproductive cycle that responds to temperature regimes in its habitats such as rivers, lakes, and reservoirs (Mouthon and Parghentanian, 2004).

Initial spawning often takes place in spring when the temperature is at least 16$18^{\circ} \mathrm{C}$ for ten degree-days. The reproduction will seize once temperatures exceed 27-28 C (McMahon, 2002; Mouthon, 2001) which will resume the temperature is optimum again (Mouthon and Parghentanian, 2004). Besides that, salinity also plays an essential role in bivalve mollusks' reproductive development. When their environments are hyper or hyposaline, shells will close as a typical response to protect internal organs from their surroundings.

The salinity in the present study was in the optimal range for broodstock conditioning. Besides, dissolved oxygen (DO) was controlled by supplying aerator to maintain good water quality even 
though macrobenthic organisms generally tolerates DO levels (Miller et al., 2002; Sousa et al., 2008). Nonetheless, low DO levels have been said to cause acidosis in aquatic animals as a result of hypercapnia due to the lowered pH. Ammonia could also affect the mortality in adults when its level is in excess. Therefore, ammonia levels were monitored closely in this experiment. In terms of $\mathrm{pH}, \mathrm{C}$. fluminea can tolerate as low as 5.4 . If $\mathrm{pH}$ is more significant than 6.5 , this species can survive in an environment with calcium levels of $6 \mathrm{mg} \mathrm{Ca} / \mathrm{L}$ (Sousa et al., 2008).

\section{Clearance Rate}

In this following Table 3 could be seen the clearance rate value of Asian clam when in the broodstock condition system.

Table 3. Clearance rate of Asian clam in broodstock system condition.

\begin{tabular}{lll}
\hline Parameters & No Sediment & Fine Sand Sediment \\
\hline Average of cells $/ \mathrm{mm}^{2}$ & $250 \pm 25$ & $242 \pm 14$ \\
Dilution factor $(\mathrm{mL})$ & 50 & 50 \\
Viable Density (cell/mL) & $125 \pm 12.5$ millions & $120 \pm 7.2$ millions \\
Viable Density in tank (cell/mL) & $10.4 \pm 1.4$ billions & $10.05 \pm 6.004$ billions \\
\hline
\end{tabular}

The given Table 3 reveals that viable density in the tank of Asian clam broodstock was $10.4 \pm 1.4$ billion for control when $242 \pm 14$ billion for fine sand sediment. The average of cells $/ \mathrm{mm}^{2}$ on both treatments was 242-250 cells $/ \mathrm{mm}^{2}$ and viable density in cell $/ \mathrm{mL}$ was $125 \pm 12.5$ million higher a quarter than fine sand sediment.

Last but not least, the clearance rate in broodstock condition was in the range of 9.3 - 10.4 billion cells $/ \mathrm{mL}$. This data indicated that food availability (microalgae) is sufficient for adult $C$. fluminea during broodstock conditioning. According to McMahon and Bogan (2001), suspension-feeding rates of $C$. fluminea can be high and varies between 300-2500 L/h. Factors that influence clearance rates of bivalves include body mass, temperature, food quality and food quantity . Clearance rates have been shown to scale allometrically in the form of bivalve dry tissue weight (Cheng, 2015), which appears to improve with increasing C. fluminea dry weight (Cheng, 2015). Several studies have also demonstrated the effects of food quality and quantity on the clearance rate of $C$. fluminea. Cheng (2015) reported that the concentration of particle size that is smaller than $53 \mu \mathrm{m}$ declined downstream, where it was highly populated with $C$. fluminea. Moreover, it was discovered that C. fluminea filters particles that are less than $1 \mu \mathrm{m}$. The same study recorded the presence of pseudo feces when diets included particles larger than $16 \mu \mathrm{m}$ which was an indication of wasteful feeding. In conclusion, C. fluminea feed most efficiently on particles within the sizes of 1-53 $\mu \mathrm{m}$.

\section{Estimating Numbers of Asian Clam (Corbicula fluminea) Production Rate}

The number of larvae production rate $C$. fluminea monthly during a year could be seen in the following Table 4 . 
Table 4. Asian Clam (Corbicula fluminea) larvae production rate during a year.

\begin{tabular}{|c|c|c|c|c|c|}
\hline \multirow{2}{*}{ Month } & \multicolumn{4}{|c|}{ Number of Larvae } & \multirow{2}{*}{$\begin{array}{l}\text { Average } \\
\text { (Ind/L) }\end{array}$} \\
\hline & Total (Ind/L) & Average (Ind/L) & per individual & per cm2 & \\
\hline Jan & 14148 & $3537 \pm 254$ & 472 & 34 & \\
\hline Feb & 14144 & $3536 \pm 117$ & 471 & 34 & 14145 \\
\hline Mar & 14144 & $3536 \pm 179$ & 471 & 34 & \\
\hline Apr & 18650 & $4663 \pm 216$ & 622 & 45 & \\
\hline May & 18700 & $4675 \pm 404$ & 623 & 45 & 18583 \\
\hline Jun & 18400 & $4600 \pm 312$ & 613 & 44 & \\
\hline Jul & 16900 & $4225 \pm 226$ & 563 & 41 & \\
\hline Aug & 17000 & $4250 \pm 103$ & 567 & 41 & 16883 \\
\hline Sep & 16750 & $4188 \pm 123$ & 558 & 40 & \\
\hline Oct & 22500 & $5625 \pm 154$ & 750 & 54 & \\
\hline Nov & 22350 & $5588 \pm 314$ & 745 & 54 & 22438 \\
\hline Dec & 22464 & $5616 \pm 103$ & 749 & 54 & \\
\hline
\end{tabular}

The production of larva in Table 4 elucidates that the Asian clam adult pattern released larvae monthly during a year wherein the great number larvae were produced 22464 Ind/L totally in December as the highest, with average $5616 \pm 103$, per individual 749 and 54 per $\mathrm{cm}^{2}$. While in February and March were the lowest larvae produced with 14144 Ind/L, the average $3536 \pm 117$, per individual 471 and 34 per $\mathrm{cm}^{2}$.
Besides that, the produced larvae in Oct and Nov were almost similar to Dec with range 22350-22500, the production larvae in three months (Apr-Jun) was higher $25 \%$ from the following three months with approximately 16800 Ind/L.

\section{Ingestion Growth Rate (IGR)}

In this following Table 5 could be seen the Asian clam (C. fluminea) larvae ingestion growth rate.

Table 5. The Asian clam larvae ingestion growth rate.

\begin{tabular}{ll}
\hline \multicolumn{1}{c}{ Study } & \multicolumn{1}{c}{ Ingestion Rate } \\
\hline C. fluminea with sediment Present study & $1.126 \pm 0.534 \mu \mathrm{g} / \mathrm{h}$ \\
C. fluminea control treatment Present study & $1.609 \pm 0.434 \mu \mathrm{g} / \mathrm{h}$ \\
Asian Clam 2019 (Bolam et al., 2019) & $2.45 \pm 0.83 \mu \mathrm{g} / \mathrm{h}$ \\
\hline
\end{tabular}

The given Table 5 elaborates the ingestion growth rate of Asian clam on fine sand sediment was $1.126 \pm 0.534$ $\mu \mathrm{g} / \mathrm{h}$ while control treatment $1.609 \pm$ $0.434 \mu \mathrm{g} / \mathrm{h}$ categorized as well. The result in this study was compared to the previous study by Bolam et al. (2019) where the ingestion rate was $2.45 \pm 0.83 \mu \mathrm{g} / \mathrm{h}$.

C. fluminea is known as a simultaneous hermaphrodite due to its ability to self-fertilize and spread its sperm through the water column (Denton et al., 2012). Larvae are brooded inside the branchial gills of adult clams upon fertilization. In the present study, the aim is to acquire the best condition for larvae production.

The larva production of the Asian clam adult had two time periods to produce larvae with great number wherein the great number larvae were produced 22464 Ind/L totally in December as the highest and in Oct and Nov was almost similar with Dec with range 22350-22500 Ind/L. The larvae production in these three months could be used to supply the hatchery process. The rate of larvae production in this experiment is in line with a study by McMahon (2002). C. fluminea has a high fecundity $(25,000$ to 75,000 veligers produced during an individual's lifetime) where egg fertilization occurs internally, and the larval clams are brooded on the gill where they transform into juveniles within 4-5 days (Natale et al., 2014).

The investigation support research as well conducted by (Cao et al. 2017), 
where the spawned $C$. fluminea would reach the peak of production during OctDec in a year. Several factors influence broodstock conditioning, particularly food availability, which appeared to catalyze $C$. fluminea spawning to meet the energetic demand of brooding (Mouthon, 2001). When food is not a limiting factor, gonad development and fecundity are improved, besides increasing the brooding and individual size of developing embryos (Beekey and Karlson, 2003).

Studies have also reported that initial broodstock condition and the gametogenesis phase the adults are in when conditioning begins are responsible for the differences in conditioning and spawning success or larval viability (Ojea et al., 2004; Denton et al., 2012). Besides, temperatures above $16 \mathrm{C}$ are necessary for reproduction to occur besides reducing bivalve metabolism.

\section{CONCLUSION}

In conclusion, this study confirmed that the time in season four (Oct-Dec) is used to establish $C$. fluminea seed since a significant number of larvae were produced.

\section{ACKNOWLEDGEMENT}

We want to thank the Ministry of Education Malaysia with the study grant Trans disciplinary Research Grant Scheme (TRGS) (R/TRGS/A0.700/000387A/007/ 2016/000391).

\section{REFERENCES}

Beekey M.A. and Karlson R.H., 2003. Effect of food availability on reproduction and brood size in a freshwater brooding bivalve. Canadian Journal of Zoology, 81(7), pp. 1168-1173. https://doi.org/10. 1139/z03-103.

Bolam, B.A., Rollwagen-Bollens, G. and Bollens, S.M., 2019. Feeding rates and prey selection of the invasive Asian clam, Corbicula fluminea, on microplankton in the Columbia River, USA. Hydrobiologia, 833(1), pp.107-123. https://doi.org/10. 1007/s10750-019-3893-z.

Cao, L., Damborenea, C., Penchaszadeh, P.E. and Darrigran, G., 2017. Gonadal cycle of Corbicula fluminea (Bivalvia: Corbiculidae) in Pampean streams (Southern Neotropical Region). PLoS ONE, 12(10), pp. 116. https://doi.org/10.1371/ journal.pone.0186850.

Cataldo, D.H., Boltovskoy, D., Stripeikis, J. and Pose, M., 2001. Condition index and growth rates of field caged Corbicula fluminea (Bivalvia) as biomarkers of pollution gradients in the Paraná river delta (Argentina). Aquatic Ecosystem Health \& Management, 4(2), pp.187-201. https://doi.org/10.1080/14634980 127712.

Cheng, K.M., 2015. The Asian Clam Corbicula fluminea: Seasonal Filtration Rates of Representative Populations in Two Tributaries of the Delaware River. Masters thesis. Drexel University.

Colwell, H., Ryder, J., Nuzzo, R., Reardon, M., Holland, R. and Wai, H.W., 2017. Invasive Asian clams (Corbicula fluminea) recorded from 2001 to 2016 in Massachusetts, USA. Management of Biological Invasions, 8(4), pp. 507-515. https://dx.doi.org\%2F10.3391\%2F mbi.2017.8.4.05.

Costil, K., Royer, J., Ropert, M., Soletchnik, P. and Mathieu, M., 2005. Spatio-temporal variations in biological performances and summer mortality of the Pacific oyster Crassostrea gigas in Normandy (France). Helgoland Marine Research, 59(4), pp.286-300. DOI 10.1007/s10152-005-0004-5.

Denton, M.E., Chandra, S., Wittmann, M.E., Reuter, J. and Baguley, J.G., 2012. Reproduction and population structure of Corbicula fluminea in an oligotrophic subalpine lake. Journal of Shellfish Research, 31(1), pp.145152. https://doi.org/10.2983/035. 031.0118. 
Filgueira, R., Comeau, L.A., Landry, T., Grant, J., Guyondet, T. and Mallet, A., 2013. Bivalve condition index as an indicator of aquaculture intensity: a meta-analysis. Ecological indicators, 25, pp.215-229. https:// doi.org/10.1016/j.ecolind.2012.10. 001.

Lee, S. W., Wee, W., Che Manan, Z., Amin, M.R. and Hajisamae, S., 2013. A study of Edwardsiella tarda colonizing live Asian clam, Corbicula fluminea, from Pasir Mas, Kelantan, Malaysia with the emphasis on its antibiogram, heavy metal tolerance, and genetic diversity. Veterinarski Arhiv, 83(3), pp. 323-331. https:// www.semanticscholar.org/paper/Astudy-of-Edwardsiella-tardacolonizing-live-Asian-LeeSeongWee/498e451b2eb5a52abc61fbfc6 1 aa537bbb2e9c57

McMahon, R.F. and Bogan, A.E., 2000. Mollusca: Bivalvia. In J. H. Thorp and A. P. Covich, editors. Ecology and classification of North American freshwater invertebrates, $2^{\text {nd }}$ edition. San Diego, CA: Academic Press. pp. 331-430.

McMahon, R.F., 2002. Evolutionary and physiological adaptations of aquatic invasive animals: $r$ selection versus resistance. Canadian Journal of Fisheries and Aquatic Sciences, 59 (7), pp. 1235-1244. https://doi.org/ 10.1139/f02-105.

Mouthon, J., 2001. Life cycle and populations dynamics of the Asian clam Corbicula fluminea (Bivalvia: Corbiculidae) in the Saone River at Lyon (France). Hydrobiologia, 452 (1), pp. 109-119. https://dx.doi.org \%2F10.1023\%2FA\%3A1011980011 889.

Mouthon, J. and Parghentanian, T., 2004. Comparison of the life cycle and population dynamics of two Corbicula species, C. fluminea and C. fluminalis (Bivalvia: Corbiculidae) in two French canals. Archiv für Hydrobiologie, 161(2), pp.267-287. https://dx.doi.org/10. 1127/0003-9136/2004/0161-0267. Natale, B.P.E., Wunderlich, M. and Resler S., 2014. Follow-up Survey of Asian clams (Corbicula fluminea) in Owasco Lake, Cayuga County, NY, 2013. A Report to the Cayuga County Soil and Water Conservation District, Cayuga County Dept. of Planning and Economic Development, and the Cayuga County Water Quality Management Agency's Owasco Lake Asian Clam Task Force. New York: Government office.

Ojea, J., Pazos, A.J., Martınez, D., Novoa, S., Sanchez, J.L. and Abad, M., 2004. Seasonal variation in weight and biochemical composition of the tissues of Ruditapes decussatus in relation to the gametogenic cycle. Aquaculture, 238(1-4), pp.451-468. https://doi.org/10.1016/j.aquacult ure.2004.05.022

Patrick, C.H., Waters, M.N. and Golladay, S.W., 2017. The distribution and ecological role of Corbicula fluminea (Müller, 1774) in a large and shallow reservoir. BioInvasions Record, 6(1). pp. 39-48. https://doi.org/10.3391/bir. 2017.6.1.07.

Rajagopal, S., Velde, G. and Vaate, A., 2000. Reproductive biology of the Asiatic clams Corbicula fluminalis and Corbicula fluminea in the river Rhine. Archiv für Hydrobiologie, 149 (3), pp.403-420. https://dx.doi.org /10.1127/archiv-hydrobiol/149/ 2000/403.

Rak, A.E., 2006. Water quality and shellfish related gastrointestinal disease cases in Kota Bharu, Kelantan, Malaysia. Masters Project Report Universiti Teknologi Malaysia.

Scarlet, M.P.J., Halldórsson, H.P. and Granmo, A., 2015. Scope for growth and condition index in the clam Meretrix meretix (L.) as biomarkers of pollution in Espírito Santo Estuary, Mozambique. Regional Studies in Marine Science, 1, pp.63- 
71. https://doi.org/10.1016/j.rsma. 2015.03.002

Sousa, R., Antunes, C. and Guilhermino, L., 2008. Ecology of the invasive Asian clam Corbicula fluminea (Müller, 1774) in aquatic ecosystems: an overview. Annales de Limnologie - International Journal of Limnology, 44(2), pp. 85-94. https: //doi.org/10.1051/limn:2008017.

Utting S.D. and Spencer, B.E., 1991. The hatchery culture of bivalve mollusc larvae and juveniles. Ministry of Agriculture Fisheries And Food Directorate Of Fisheries Research. Lowestoft, 68, $31 \mathrm{p}$.

Willadino, L., Souza-Santos, L.P., Mélo, R.C., Brito, A.P., Barros, N.C., Araújo-Castro, C.M., Galvão, D.B., Gouveia, A., Regis, C.G. and Cavalli, R.O., 2012. Ingestion rate, survival and growth of newly released seahorse Hippocampus reidi fed exclusively on cultured live food items. Aquaculture, 360, pp.10-16. https://doi.org/10.1016/j.aquacult ure.2012.06.025. 